\title{
Criteria for the Appropriate Drug Utilisation of Immunoglobulin
}

\author{
Petra Thürmann and Sebastian Harder \\ Department of Clinical Pharmacology, University Hospital Frankfurt/Main, \\ Frankfurt am Main, Germany
}

\section{Contents}

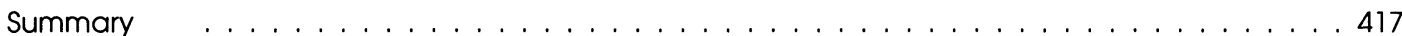

1. Preparation of Intravenous Immunoglobulin (IVIG) $\ldots \ldots \ldots \ldots$

2. Pharmacology of Immunoglobulin $G \ldots \ldots \ldots$

3. Established Indications for the Use of IVIG . . . . . . . . . . . . . . . . . . . . . . . . . . . . . . . . . 419

3.1 Established Primary Immunodeficiency . . . . . . . . . . . . . . . . . . . . . .420

3.2 Paediatric AIDS Patients . . . . . . . . . . . . . . . . . . . . . . . . . . . . . .420

3.3 Chronic Lymphoma and Multiple Myeloma . . . . . . . . . . . . . . . . . . . . . . . . . . . 420

3.4 Idiopathic Thrombocytopenic Purpura and Kawasaki Disease . . . . . . . . . . . . . . 421

3.5 Allogeneic Bone Marrow Transplantation . . . . . . . . . . . . . . . . . . . . . . . . . . . . . 422

3.6 Renal Transplantation . . . . . . . . . . . . . . . . . . . . . . . . . . . . . . . . . .423

3.7 Septicaemia . . . . . . . . . . . . . . . . . . . . . . . . . . . . . . . . . . . . . 424

3.8 Preterm Neonates with Low Birthweight . . . . . . . . . . . . . . . . . . . . . . . . . . . . 425

3.9 Other Indications for IVIG . . . . . . . . . . . . . . . . . . . . . . . . . . . . . . . . . 426

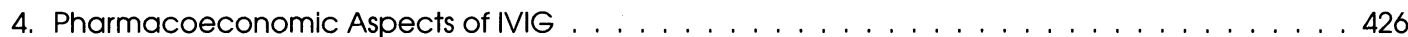

\section{Summary}

Intravenous immunoglobulins (IVIGs) are prepared from human plasma pools and further modified enzymatically or chemically. Despite careful selection of donors and inclusion of effective virus elimination steps in the production process, contamination with hepatitis $C$ virus can still occur.

IVIGs possess most of the characteristics of native immunoglobulins, such as antigen neutralisation and complement activation. The serum half-life of native immunoglobulin is about 21 days, and comparable half-lives have been reported for several IVIG preparations.

IVIGs have received general approval for the treatment of primary immunodeficiencies such as agammaglobulinaemia. Of the secondary immunodeficiencies, only paediatric AIDS, chronic lymphocytic leukaemia and multiple myeloma, as well as allogeneic bone marrow transplantation, are accepted indications for IVIGs. Because of their immunomodulatory action, IVIGs are also recommended for the treatment of idiopathic thrombocytopenic purpura, Kawasaki disease (mucocutaneous lymph node syndrome) and, recently, Guillain-Barré syndrome. IVIGs have been investigated in a wide range of immunodeficient states (e.g. prematurity) and autoimmune diseases (e.g. multiple sclerosis), but conclusive results are not available.

Since IVIGs are associated with a certain risk of transmission of viral infec- 
tions and, secondly, because they are generally acknowledged as expensive drugs, their use requires careful consideration of risk, benefit and cost.

Intravenous immunoglobulins (IVIGs) are used for the treatment of a variety of symptoms and diseases. IVIGs are expensive drugs, the acquisition costs of which may account for up to $10 \%$ of overall drug expenditures in major hospitals. ${ }^{|1,2|}$ Despite this broad utilisation, the clinical benefit of IVIG treatment has been demonstrated in controlled trials for only a few indications (e.g. bone marrow transplantation, paediatric AIDS), and small-scale studies or anecdotal experience have provided the basis for some other indications claimed for the use of IVIG [e.g. Kawasaki disease (mucocutaneous lymph node syndrome) and idiopathic thrombocytopenic purpura (ITP)] (table I).

Furthermore, utilisation patterns, as well as approved indications, for IVIG preparations differ between European countries, the US and Australia/ New Zealand. Therefore, to promote rational therapy with IVIG, several guidelines for the use of IVIG have been published (for treatment recommendations, see table I) ${ }^{[3-6]}$ The aim of this review is to summarise the well established, and some asyet uncertain, indications for IVIG.

\section{Preparation of Intravenous Immunoglobulin (IVIG)}

Most IVIG is derived from human plasma pools from at least 1000 donors, by low temperature ethanol fractionation. ${ }^{[7]}$ Further production processing includes enzymatic cleavage, chemical modifications or chromatographic steps, to eliminate aggregates and increase the intravenous tolerability of these substances. ${ }^{|8-10|}$ These modifications may result in some alterations of the protein molecules, and may also influence the pharmacokinetic properties and antigen-neutralising activity of the immunoglobulins (see section 3). ${ }^{|8,9,11-13|}$

Apart from the production process, the natural variability in donor antibody production leads to considerable differences between the antibody contents of IVIG preparations from different regions of the world, and even between batches from one manufacturer. ${ }^{[14]}$

One important aspect of IVIG is - because of their human origin - possible contamination with pathogenic viruses such as HIV, hepatitis B virus (HBV) and hepatitis $\mathrm{C}$ virus (HCV). The most effective ways of eliminating such contamination involve physical and chemical treatment such as wet heat, irradiation or the solvent-detergent method. ${ }^{[15-21]}$ However, several reports of infection with HCV, possibly due to IVIG, have been published in the literature. ${ }^{[22-24]}$ At present, most manufacturers use only plasma from donors who are negative for hepatitis B surface antigen ( $\mathrm{HBsAg}$ ) and antibodies to HBV (anti-HBV), HCV (antiHCV), HIV-1 and HIV-2 (anti-HIV-1; anti-HIV2). ${ }^{[16]}$

\section{Pharmacology of Immunoglobulin $G$}

Immunoglobulins of the $\mathrm{G}$ class have a molecular weight of 150000 and a sedimentation coeffi-

Table I. Criteria for intravenous immunoglobulin (Ig) treatment in established indications

\begin{tabular}{ll}
\hline Indication & Diagnostic or clinical criteria \\
\hline $\begin{array}{l}\text { Primary immunodeficiency, X-chromosome-linked } \\
\text { agammaglobulinaemia, common variable immunodeficiency }\end{array}$ & Total lg level $<5-6 \mathrm{~g} / \mathrm{L}$, recurrent infections $^{[3,4]}$ \\
Bone marrow transplantation (BMT) & In allogeneic BMT only ${ }^{[4,5]}$ \\
Paediatric AIDS & Only CD4+lymphocyte counts $>0.2 \times 10^{9} / \mathrm{L}^{[4,5]}$ \\
Malignant lymphoma and myeloma & Total lg level $<5-6 \mathrm{~g} / \mathrm{L}$, recurrent infections \\
Idiopathic thrombocytopenic purpura, post-transfusion purpura & Corticosteroid-resistant cases and/or platelet count $<20 \times 10^{9} / \mathrm{L}$, \\
& acute bleeding \\
Kawasaki disease (mucocutaneous lymph node syndrome) & Immediate treatment after diagnosis \\
\hline
\end{tabular}


Table II. Subclasses of immunoglobulin G (IgG) and their pharmacokinetic characteristics, determined in healthy volunteers ${ }^{[25]}$

\begin{tabular}{|c|c|c|c|c|c|c|}
\hline Subclass & $\begin{array}{l}\text { Mean serum } \\
\text { level }(g / L)[ \pm S D]\end{array}$ & Total IgG (\%) & $\begin{array}{l}\text { Mean biological } \\
\text { half-life (days) }[ \pm S D]\end{array}$ & $\begin{array}{l}\text { Mean intravascular } \\
\text { pool }^{\mathrm{a}}(\mathrm{mg} / \mathrm{kg})[ \pm \mathrm{SD}]\end{array}$ & $\begin{array}{l}\text { Fractional } \\
\text { catabolic rate }^{\mathrm{b}}\end{array}$ & $\begin{array}{l}\text { Mean turnover rate } \\
(\mathrm{mg} / \mathrm{kg} / \mathrm{day})[ \pm \mathrm{SD}]\end{array}$ \\
\hline $\operatorname{lgG}_{1}$ & $6.6 \pm 1.7$ & 61.0 & $21 \pm 5$ & $298 \pm 108$ & 0.08 & $25 \pm 14$ \\
\hline $\lg G_{2}$ & $3.2 \pm 1.1$ & 29.5 & $20 \pm 2$ & $134^{d}$ & 0.07 & $9.4^{\mathrm{d}}$ \\
\hline $\lg _{3}$ & $0.6 \pm 0.3$ & 5.3 & $7 \pm 1$ & $20 \pm 5$ & 0.17 & $3.4 \pm 0.7$ \\
\hline $\operatorname{lgG}_{4}$ & $0.5^{\mathrm{d}}$ & 4.2 & $21 \pm 3$ & $19^{d}$ & 0.07 & $1.3^{d}$ \\
\hline \multicolumn{7}{|c|}{ a The intravascular pool is the amount of IgG present in plasma in relation to bodyweight. } \\
\hline \multicolumn{7}{|c|}{ b The fractional catabolic rate is the proportion of intravascular IgG that is catabolised per day. } \\
\hline \multicolumn{7}{|c|}{ c The turnover rate is the IgG turnover per day (catabolic rate $\times$ intravascular pool). } \\
\hline \multicolumn{7}{|c|}{$\begin{array}{l}\text { d Data were obtained in different studies and the figures given for } \lg _{2} \text { and } \lg G_{4} \text { were calculated from average values; therefore, no } S D \text { is } \\
\text { given. }\end{array}$} \\
\hline \multicolumn{7}{|c|}{ Abbreviation: $\mathrm{SD}=$ standard deviation. } \\
\hline
\end{tabular}

cient of $7 \mathrm{~S}$. Native immunoglobulin $\mathrm{G}$ (IgG) is comprised of 4 subclasses with different half-lives and functions (table II). ${ }^{|25|} \mathrm{IgG}_{1}$, the major component (about $61 \%$ ) of IgG, is involved in virus inactivation (via specific antibodies, e.g. anti-HAV), complement activation and opsonisation by initiating the uptake and degradation of phagocytosing cells. Complement activation can only be induced by $\mathrm{IgG}_{1}, \mathrm{IgG}_{2}$ and $\mathrm{IgG}_{3}$; furthermore, macrophages and neutrophil granulocytes can only recognise and phagocytose antigens opsonised by $\mathrm{IgG}_{1}$ and $\mathrm{IgG}_{3}$ molecules. ${ }^{|25|}$ IgGs also include antibodies against superantigens such as staphylococcal toxins. ${ }^{\mid 26]}$

As early as 1981, an additional immunomodulating action of IVIG was demonstrated in patients with ITP. ${ }^{[27]}$ It has been proposed that IgGs block and modulate $F_{c}$ receptors, ${ }^{|26|}$ and they may also down-regulate interleukin production. ${ }^{[28 \mid}$

In healthy individuals, the half-life of native $\mathrm{IgG}$ ranges from 21 days for intact $\mathrm{IgG}_{1}, \mathrm{IgG}_{2}$ and $\mathrm{IgG}_{4}$ to about 7 days for $\mathrm{IgG}_{3},{ }^{\mid 25]}$ a comparable average half-life of 22 days has been found for total IgG in IVIG preparations. ${ }^{[29,30]}$ About $50 \%$ of the IgGs are present in the intravascular space, the remainder being distributed in the tissues and extravascular fluids. However, in patients with various diseases, much shorter half-lives of between 30 hours ${ }^{|31,32|}$ and 3 to 5 days ${ }^{[33]}$ have been reported.

The catabolism of IgG is influenced by various factors such as the actual serum level and type of disease. ${ }^{[33]}$ Since half-life depends on the integrity of the molecules and the production process (i.e. pepsin treatment and other chemical modifications), cleavage of the $F_{c}$ fragment (resulting in $5 \mathrm{~S}$ IVIG) results in a considerable alteration in halflife and function. ${ }^{[8,11,34]} 5 \mathrm{~S}$ IVIG has a much shorter half-life, of about 2 days. Because of the lack of the $F_{c}$ moiety, activation of effector cells (i.e. immunomodulation) will not occur. ${ }^{[34]}$

\section{Established Indications for the Use of IVIG}

Generally accepted recommendations for the use of IVIG in certain diseases are given in table I. Indications approved by the US Food and Drug Administration include the maintenance treatment of patients with established immunodeficiency, particularly primary defects (e.g. agammaglobulinaemia, hypogammaglobulinaemia) [section 3.1]. Furthermore, prevention of bacterial infections in children with symptomatic HIV infection (section 3.2) and treatment of patients with chronic lymphocytic leukaemia (CLL) [section 3.3] as secondary immunodeficiencies are also generally acknowledged indications for IVIG.

Among the large number of autoimmune disorders, IVIG is considered to be an effective treatment for ITP and Kawasaki disease (section 3.4). Different opinions exist with regard to the therapeutic use of IVIG in allogeneic bone marrow transplantation (BMT) and other organ transplantations (sections 3.5 and 3.6), the prevention of septic shock syndrome (section 3.7 ) and in preterm 
neonates (section 3.8). Apart from these more or less accepted indications, IVIG has been investigated in a number of other disorders (e.g. myasthenia gravis and recurrent miscarriage) [section 3.8].

\subsection{Established Primary Immunodeficiency}

The most common antibody deficiency is the variable immune deficiency (VID), which is associated with low serum levels of IgG and immunoglobulin A $(\operatorname{IgA})$, and the X-chromosome-linked agammaglobulinaemia. Furthermore, subclass deficiencies and specific antibody deficiencies have been observed in patients with normal serum levels of total IgG, IgA and IgM. ${ }^{\mid 3]}$

Untreated patients with hypo- or agammaglobulinaemia often experience recurrent infections, and long term complications include bronchiectasis, malabsorption and anaemia. IgG replacement therapy aims to prevent acute and chronic complications through substitution of a wide spectrum of antibodies. ${ }^{[6]}$ It has been shown in several trials that treatment with intramuscular (IM) IgG reduces the occurrence of severe infections in comparison with no treatment, and that higher doses, administered intravenously, offer even more clinical benefit. ${ }^{[6]}$

Different recommended dosage regimens do exist, with dosages of 0.4 to $0.6 \mathrm{~g} / \mathrm{kg}$ given every 4 weeks being associated with fewer infections than the earlier recommended dosages of 0.1 to 0.2 g/kg. ${ }^{[6,35]}$ Treatment efficacy (i.e. reduction in recurrence of infections and complications in a given patient) can only be determined retrospectively. Therefore, serum levels of IgG serve as surrogate end-points, although they do not necessarily correlate with efficacy. ${ }^{[6]}$ Furthermore, treatment with immunoglobulin must be individualised for each patient because of different rates of catabolism; the goal of therapy should be to achieve circulating IgG levels $>5$ to $6 \mathrm{~g} / \mathrm{L} \cdot \cdot^{[3,4,36]}$ In most patients, normalisation of serum IgG levels can be achieved by dosage or interval manipulation. Unfortunately, long term studies investigating the efficacy of different dosages and dosage regimens have not yet been published.

\subsection{Paediatric AIDS Patients}

Although children with AIDS do have normal serum IgG levels, their antibody responses are poor, increasing the incidence of bacterial and viral infections in these patients. In contrast to adults with AIDS, children do not have the chance to develop antibodies against various micro-organisms before developing AIDS.

Several trials in children with AIDS demonstrated a reduction in febrile and infectious episodes, as well as a reduction in duration of hospitalisation, after treatment with IVIG. ${ }^{[37,38]}$ In a doubleblind, multicentre trial, ${ }^{[39]} 372$ symptomatic children with AIDS were given IVIG $0.4 \mathrm{~g} / \mathrm{kg} / \mathrm{month}$ or placebo over 2 years. Overall, children receiving IVIG had fewer serious infections than those receiving placebo (33\% vs $42 \%$ ). In particular, children with CD4+ lymphocyte counts $>0.2 \times 10^{9} / \mathrm{L}$ showed the largest benefit, whereas more severely ill children (with CD4+ counts $<0.2 \times 10^{9} / \mathrm{L}$ ) did not benefit from IVIG treatment. ${ }^{[39]}$

At the time of that trial, antiretroviral treatment and Pneumocystis carinii prophylaxis was not routinely administered to all children. Ongoing trials will evaluate the true benefit of IVIG in the context of current clinical management of children with AIDS. Since data from these trials are not yet available, IVIG treatment in paediatric AIDS patients may be recommended using the above-mentioned dosage regimen.

\subsection{Chronic Lymphoma and Multiple Myeloma}

Infections are a common cause of morbidity and mortality in patients with CLL or multiple myeloma (MM). Hypogammaglobulinaemia, which occurs in about 10 to $50 \%$ of these patients, is assumed to be an important contributing factor. ${ }^{[6]}$ Furthermore, reduced numbers of T-helper cells and impaired $\mathrm{T}$ cell function have been described in patients with CLL. ${ }^{[40]}$

In a crossover study, ${ }^{[41]} 12$ patients (8 with CLL and 4 with non-Hodgkin's lymphoma) with IgG levels $<3.5 \mathrm{~g} / \mathrm{L}$ or a history of serious infections 
received either placebo or IVIG $0.4 \mathrm{~g} / \mathrm{kg}$ every 3 weeks for 1 year. The incidence of severe and less severe infections was significantly reduced during IVIG treatment, compared with placebo $(p=0.001)$. Almost no serious complications occurred when IgG levels were $>6.4 \mathrm{~g} / \mathrm{L}$.

The Cooperative Group Trial ${ }^{|42|}$ showed that IVIG $0.4 \mathrm{~g} / \mathrm{kg}$ every 3 weeks for 1 year was effective in preventing bacterial infections in patients who had CLL in conjunction with hypogammaglobulinaemia and/or a history of 1 or more serious infections. No prophylactic antibiotics were given. Among the 57 patients completing 1 year of treatment, 14 bacterial infections occurred in the 28 IVIG-treated patients, and 36 bacterial infections occurred in the 29 placebo-treated patients $(\mathrm{p}=0.01)$. IVIG-treated patients remained free of serious infections for a longer period of time than control patients. IVIG-treatment had no effect on the incidence of viral or fungal infections. Mortality rates were comparable between groups ( 3 deaths in each group).

Schedel ${ }^{[43]}$ investigated the efficacy of IVIG $10 \mathrm{~g}$ versus placebo, given every 3 to 4 weeks over 6 months to 93 patients with MM. A prerequisite for inclusion was an IgM serum level $<0.5 \mathrm{~g} / \mathrm{L}$ in patients with IgA or IgM myeloma, or subnormal $\operatorname{IgG}$ and $\operatorname{IgA}$ levels in patients with monoclonal IgM myeloma. Infectious complications occurred significantly less often in patients receiving IVIG therapy $(\mathrm{p}<0.01)$.

In a recent trial, ${ }^{[44]}$ the usefulness of IVIG as prophylaxis against infections was studied in patients with MM. In 82 patients with stable MM, IVIG $(0.4 \mathrm{~g} / \mathrm{kg})$ or placebo was given monthly for 1 year. No prophylactic antibiotics were given. There were no episodes of septicaemia or pneumonia in patients treated with IVIG $(n=41)$, versus 10 in placebo recipients $(n=41)$. The rate of serious infections was also lower in IVIG-treated patients, but mortality data were not reported. Stratification of the data according to platelet counts and haemoglobin levels showed that only patients with adequate bone marrow function (i.e. platelet count $>150 \times 10^{9} / \mathrm{L}$ and haemoglobin levels $>11$ $\mathrm{g} / \mathrm{L}$ ) benefitted from IVIG therapy.

From these trials it can be concluded that, in particular, patients with low IgG levels derive benefit from IVIG therapy, since the incidence of bacterial infections was reduced in all trials. However, IVIG therapy did not influence viral or mycotic infections, and it is doubtful whether patients should be selected for therapy according to their baseline IgG levels or the incidence and severity of infections.

In addition, no survival benefit of IVIG therapy has been shown in any of these trials. A costeffectiveness analysis of prophylactic IVIG in CLL patients was performed using data from the Cooperative Group Trial ${ }^{[42]}$ and decision analysis techniques. ${ }^{[45]}$ In that study, IVIG therapy resulted in a gain of 0.8 days of quality-adjusted life expectancy per year of IVIG treatment, giving a cost of over \$US5 million for each quality-adjusted life year gained. IVIG treatment might even lead to a reduction in quality-adjusted life expectancy when the inconvenience of treatment is taken into account.

Nevertheless, IVIG is recommended for the prevention of infection in patients with CLL or MM in some current guidelines, ${ }^{[4,5]}$ but only in patients with IgG levels $<6.0 \mathrm{~g} / \mathrm{L}$ and who have had more than 2 bacterial infections within 1 year, or in whom there is evidence of specific antibody deficiency. The dosage should be $0.4 \mathrm{~g} / \mathrm{kg}$ every 3 to 6 weeks to maintain serum IgG levels $>6 \mathrm{~g} / \mathrm{L}$. ${ }^{[5]}$

\subsection{Idiopathic Thrombocytopenic Purpura and Kawasaki Disease}

IVIG is indicated for the treatment of ITP in both children and adults, but should be reserved for patients who do not respond to corticosteroids, or in whom the platelet count has decreased to $<20 \times 10^{9} /$ Lor bleeding has occurred. Administration of immunoglobulin is not curative, but it may prevent major bleeding-associated complications such as intracranial haemorrhage until remission occurs or another therapeutic intervention can be implemented. ${ }^{[46-48]}$ The overall response to IVIG is vari- 
able, with adults generally responding less often than children. ${ }^{|46,47|}$

The usual dosage in patients with ITP is IVIG $0.4 \mathrm{~g} / \mathrm{kg}$ for 5 consecutive days. ${ }^{\mid 4,51}$ However, Kurlander et al. ${ }^{\mid 49}$ compared this schedule for treating ITP in adults with a shorter schedule (IVIG $1 \mathrm{~g} / \mathrm{kg}$ for 2 days). Both schedules were found to be effective, with response being attained in 11 of 17 patients receiving the 5-day regimen and in 9 of 10 patients on the 2 -day regimen. ${ }^{|49|}$

The efficacy of IVIG plus aspirin (acetylsalicylic acid) in patients with Kawasaki disease has been demonstrated versus aspirin alone. ${ }^{\mid 50,51]}$ Once the diagnosis of Kawasaki disease has been ascertained, IVIG $0.4 \mathrm{~g} / \mathrm{kg} /$ day plus aspirin should be given for 5 days. Alternatively, IVIG $2 \mathrm{~g} / \mathrm{kg}$ on 1 day - similar to the short term treatment of ITP has also been suggested. ${ }^{\mid 4-6]}$

In conclusion, the usefulness of IVIG in patients with ITP and Kawasaki disease has been demonstrated convincingly ${ }^{|46-50|}$ and the aforementioned dosage schemes are equivocally recommended in all current therapeutic guidelines for the use of IVIG. ${ }^{\mid 3-6]}$

\subsection{Allogeneic Bone \\ Marrow Transplantation}

Acute graft-versus-host disease (GVHD) and infectious complications are associated with substantial morbidity and mortality in patients receiving an allogeneic BMT. In the past, cytomegalovirus (CMV) infection was the main cause of fatal infections in BMT patients, but the use of screened blood products and antiviral prophylaxis with aciclovir and ganciclovir have significantly reduced the incidence of CMV infection. ${ }^{|52|}$ Despite improved prophylaxis, CMV seropositive patients receiving their graft from a CMV seropositive donor remain at high risk for CMV infection posttransplantation.

In one study, ${ }^{1531} 38 \mathrm{CMV}$ seronegative ('low risk') patients who received bone marrow from CMV seronegative donors (and no leucocyte transfusions) were given IVIG $1 \mathrm{~g} / \mathrm{kg}$ as an initial dose before conditioning therapy, followed by once weekly administration post-BMT for 120 days. ${ }^{53 .}$ Compared with 37 control patients who received no IVIG therapy, viraemia was present in 12 IVIGtreated patients and 15 control patients. However, symptomatic CMV infections occurred in 7/12 viraemic IVIG-treated patients, but in all 15 viraemic patients who received no IVIG $(p=0.01)$. Furthermore, interstitial pneumonia of any cause (but not CMV-induced) was significantly reduced by IVIG therapy, as was the rate of acute GVHD, which occurred in 13/38 IVIG-treated patients and 24/37 control patients.

In another study, ${ }^{[54]}$ IVIG $0.5 \mathrm{~g} / \mathrm{kg}$ was given once before BMT, once weekly for 90 days postBMT and then monthly until 360 days post-transplantation in 191 patients. Overall survival and the incidence of acute GVHD and interstitial pneumonia in the treatment group were compared with 191 control patients. A significant reduction in acute GVHD was seen only in a subgroup of patients older than 20 years (65\% of all patients). Development of interstitial pneumonia was reduced in CMV seropositive patients over the age of 20 years, but overall survival was not improved by IVIG therapy.

The usefulness of IVIG prophylaxis of infections following allogeneic BMT was studied in 92 patients. ${ }^{[55]}$ Patients were randomly allocated to receive either no treatment or IVIG $0.5 \mathrm{~g} / \mathrm{kg}$ every 2 weeks, starting 1 week before BMT until day 100 , followed by $0.25 \mathrm{~g} / \mathrm{kg}$ every 2 weeks until day 180 . Neither overall nor disease-free survival was influenced by IVIG therapy, and the incidence of infection with Gram-negative bacteria was higher in the IVIG-treated patients.

Studies comparing IVIG containing a defined amount of anti-CMV antibody with standard IVIG have shown that anti-CMV IVIG therapy leads to a greater reduction in CMV infections; ${ }^{[56,57]}$ however, the frequency of interstitial pneumonia was only reduced in 1 of 2 studies. ${ }^{|57|}$ Survival rates were not improved with anti-CMV IVIG therapy. Thus, anti-CMV IVIG has so far not been proven to be superior to standard IVIG. This may be explained by the fact that standard IVIG contains a 
certain, but not standardised, amount of anti-CMV antibodies, and that this titre might be sufficient for the prevention of CMV infections.

For IVIG prophylaxis following BMT, patients should be stratified according to type of BMT, previous myeloablative treatment and, presumably, CMV antibody status. Autologous BMT patients do not appear to benefit from IVIG treatment. ${ }^{152 \mid}$ Clinical efficacy, in terms of prevention of CMVrelated infections, may be more pronounced in patients receiving CMV seropositive transplants; however, the superiority of anti-CMV-enriched IVIG has not yet been convincingly proven. The most reproducible effect of prophylactic IVIG seems to be the reduction of GVHD.

The recommended initial dosage of IVIG in patients receiving an allogeneic BMT is 0.5 to $1.0 \mathrm{~g} / \mathrm{kg}$ weekly or 2-weekly, starting 1 week before BMT until about 100 to 120 days post-BMT. Thereafter, the recommended dosage is 0.25 to $0.5 \mathrm{~g} / \mathrm{kg}$ every 2 weeks until day 180 post-BMT. ${ }^{|4,5|}$

\subsection{Renal Transplantation}

CMV is the major viral pathogen in renal transplant patients ${ }^{|58|}$ and contributes significantly to post-transplant complications and cost of treatment. ${ }^{[59]}$ About $60 \%$ of CMV-negative recipients $(\mathrm{R}-)$ who receive a transplant from a CMV seropositive donor $(\mathrm{D}+)$ will develop CMV-related disease.

In comparison with no IVIG treatment $(\mathrm{n}=35$ $\mathrm{R}-/ \mathrm{D}+)$, treatment with anti-CMV-enriched IVIG reduced the risk of CMV disease by about $50 \%$ in $24 \mathrm{R}-/ \mathrm{D}+$ transplant recipients. ${ }^{58 \mid}$ The only factor associated with severe CMV disease despite IVIG treatment was the administration of muromonabCD3 (OKT-3) for graft rejection. Similarly, in a randomised study reported by Conti et al., ${ }^{\mid 60]}$ IVIG was given at a dosage of $0.5 \mathrm{~g} / \mathrm{kg}$ once pre-transplantation and at 1 week post-transplantation, followed by 5 weekly doses of $0.25 \mathrm{~g} / \mathrm{kg}$, in a group of 48 high-risk patients (R-/D+) undergoing renal transplantation. All patients were receiving immunosuppression with antilymphocyte globulin, cyclosporin, azathioprine and prednisone. Compared with the control group (23 patients who did not receive IVIG prophylaxis), the incidence of lifethreatening CMV infections (e.g. hepatitis, pneumonia) was significantly reduced in the IVIG group ( $1 / 48 v s 6 / 23)$, and a trend towards reduced mortality was seen. Graft survival after 1 year was significantly improved in the IVIG group (45/48 vs 14/23).

Since highly potent antiviral drugs are now available, several trials have compared the efficacy of IVIG treatment with that of aciclovir and ganciclovir. Conti et al. ${ }^{|61|}$ showed that ganciclovir alone was as effective as IVIG in reducing CMVassociated symptoms and severe disease, as well as overall mortality, in high-risk (R-/D+) renal transplant recipients. Drug acquisition costs for ganciclovir therapy came to $\$$ US350 per patient, compared with $\$$ US4000 per patient for IVIG (currency year not stated). In addition, the duration of hospitalisation was nonsignificantly shorter during ganciclovir treatment. ${ }^{|61|}$

Nicol et al. ${ }^{|62|}$ prospectively studied 361 renal transplant patients, of whom 73 were R-/D+. High-risk patients $(\mathrm{R}-/ \mathrm{D}+)$ received low-dose aciclovir treatment $600 \mathrm{mg} /$ day orally plus antiCMV IVIG $1 \mathrm{ml} / \mathrm{kg}$ (concentration not stated) immediately before and every 3 weeks after transplantation for 6 months, and the remaining patients received aciclovir $600 \mathrm{mg} /$ day orally using the same regimen as the high-risk patients. The overall incidence of CMV-related disease was $5 \%$, and was not markedly higher $(10 \%)$ in high-risk patients, who had received anti-CMV IVIG. Again, muromonab-CD3 treatment substantially increased the risk of CMV disease.

In contrast, in an uncontrolled study, Stratta et al. ${ }^{[63]}$ showed that the addition of standard IVIG $(0.5 \mathrm{~g} / \mathrm{kg}$ for 6 doses) or anti-CMV IVIG (0.1 to $0.15 \mathrm{~g} / \mathrm{kg}$ for 5 doses) was not associated with additional benefit compared with ganciclovir plus aciclovir alone, in 82 patients with CMV-matched and unmatched status undergoing combined pancreas-kidney transplantation.

In summary, anti-CMV IVIG may be given to high-risk (R-/D+) patients undergoing renal trans- 
Table III. The use of intravenous immunoglobulin (IVIG) in septicaemia. This table shows the results of randomised, placebo-controlled clinical trials investigating the effect of IVIG as prophylaxis or treatment on mortality in patients with sepsis

\begin{tabular}{|c|c|c|c|c|c|c|}
\hline \multirow[t]{2}{*}{ Setting } & \multirow[t]{2}{*}{ No. } & \multicolumn{3}{|l|}{ Mortality } & \multirow[t]{2}{*}{ Clinical observations } & \multirow[t]{2}{*}{ Reference } \\
\hline & & placebo & IVIG & $p$-value & & \\
\hline Surgery (prophylaxis) & 329 & $22 / 112$ & $\begin{array}{l}15 / 109 \\
20 / 108^{a}\end{array}$ & $\begin{array}{l}\text { NS } \\
\text { NS }\end{array}$ & $\begin{array}{l}\text { Standard IVIG associated with a reduction in } \\
\text { infections ( } 33 \% \text { vs } 47 \% ; p=0.03 \text { ). Length of stay } \\
\text { on ICU reduced from } 6 \text { to } 4 \text { days ( } p=0.02 \text { ). } \\
\text { CLP-IVIG less effective than standard IVIG with } \\
\text { regard to the number of infections and mortality }\end{array}$ & 64 \\
\hline $\begin{array}{l}\text { Multiple trauma (head } \\
\text { injury) }\end{array}$ & 150 & $15 / 146$ & $23 / 142$ & NS & $\begin{array}{l}\text { Mortality not reduced, but significant reduction } \\
(33 \%) \text { in pneumonia }(p=0.01)\end{array}$ & 65 \\
\hline ICU & 104 & $22 / 54$ & $22 / 50$ & NS & No reduction in mortality & 66 \\
\hline $\begin{array}{l}\text { Surgery (Elebute score } \\
\geq 20 \text { ) }\end{array}$ & 62 & $22 / 33$ & $11 / 29$ & $<0.05$ & $\begin{array}{l}\text { Mortality reduced by IVIG. Death rate from septic } \\
\text { shock reduced }(p<0.05)\end{array}$ & 67 \\
\hline Sepsis (treatment) & 55 & $1 / 27$ & $9 / 28$ & $<0.01$ & $\begin{array}{l}\text { Significant reduction in mortality }(p<0.01) \text {. } \\
\text { Correlation between endotoxin levels and death }\end{array}$ & 68 \\
\hline Polytrauma and sepsis & 40 & $11 / 20$ & $8 / 20$ & NS & $\begin{array}{l}\text { Systemic infections occurred in } 23 \text { and } 33.7 \% \text { of } \\
\text { patients receiving IVIG and placebo, respectively; } \\
\text { sepsis syndrome reduced (NS) }\end{array}$ & 69 \\
\hline Peritonitis & 288 & $58 / 143$ & $66 / 145$ & NS & $\begin{array}{l}\text { Significant shortening of ventilation time }(p<0.01) \text {. } \\
\text { No reduction in mortality }\end{array}$ & 70 \\
\hline
\end{tabular}

a 108 patients received IVIG with high antibody titres against CLP.

Abbreviations: CLP = core lipopolysaccharide; ICU = intensive care unit; NS = not significant.

plantation, especially when muromonab-CD3 has to be administered. In the remaining patients, prophylaxis with antiviral drugs alone seems to be at least equally effective. There is no clear dosage recommendation, but at least 6 doses $(0.5 \mathrm{~g} / \mathrm{kg})$ should be given at weekly intervals, the first dose being given within 48 hours before renal transplantation.

\subsection{Septicaemia}

Drug utilisation reviews indicate that large quantities of IVIG are used in patients with septicaemia during their stay in an intensive care unit (ICU). ${ }^{[1]}$ Despite the empirical use of broadspectrum antibiotics, infection is still the leading cause of death among patients in ICUs. ${ }^{[64]}$ Administration of IVIG may support the defective phagocytosis and opsonic function in these patients' serum. An overview of randomised, controlled clinical trials of the use of IVIG in septicaemia is given in table III.

In 1 double-blind trial, ${ }^{|64|} 329$ patients at high risk of infection after surgery were allocated to receive one of the following: standard IVIG $0.4 \mathrm{~g} / \mathrm{kg}$ [days $1,8,15$ and $22(\mathrm{n}=109)$ ], standard IVIG with high titres of antibodies against core lipopolysaccharide (CLP) on days $1,8,15$ and $22(n=108)$, or placebo $(n=112)$. Compared with placebo, standard IVIG led to a significant reduction $(33 \%$ vs $47 \% ; \mathrm{p}=0.03$ ) in infections, particularly pneumonia. Length of stay in ICU was also significantly ( $p$ $=0.02$ ) reduced by standard IVIG, from 6 days (in the placebo group) to 4 days. However, overall mortality rates did not differ significantly between the treatment groups, ranging from $13.8 \%$ (standard IVIG) to $18.5 \%$ (IVIG with anti-CLP) and $19.6 \%$ (placebo).

A significantly lower incidence of pneumonia after IVIG treatment compared with placebo has been reported by Glinz et al., ${ }^{[65]}$ while a reduction in ventilation time and length of stay on ICU was shown in another trial. ${ }^{[6]}$ With respect to the ultimate end-point of mortality, an effect of IVIG was only demonstrated in 2 smaller studies. ${ }^{167,68]}$ A significant survival benefit (mortality rates 67 and $38 \%$ in patients receiving placebo and IVIG, respectively) was shown by Dominioni et al. ${ }^{[67]}$ in 62 patients with an Elebute score $\geq 20$. Patients in the 
active treatment group received IVIG $0.4 \mathrm{~g} / \mathrm{kg}$ on the first and second days, followed by a half-dose on day 6.

These results were confirmed by another randomised, placebo-controlled trial in patients enrolled $<24$ hours after the onset of septic shock. ${ }^{|68|}$ The results showed a significant survival improvement after IVIG. 55 patients with signs of sepsis and endotoxin concentrations $>12.5 \mathrm{ng} / \mathrm{L}$ received IVIG 600ml (IgG 38 g/L; IgM 6 g/L; IgA 6 g/L) on day 1 and $300 \mathrm{ml}$ on days 2 and 3 . The authors showed a correlation between plasma lipid A antibody levels and survival, as well as a correlation between survival and endotoxin levels.

Scrutiny of the inclusion criteria and placebo mortality rates (table III) reveals that underlying diseases and severity of disease, as well as additional treatment, differed between the published trials, impeding a simple comparison of the data. In conclusion, the usefulness of IVIG in sepsis, either as prophylactic or therapeutic treatment, has not yet been convincingly demonstrated. ${ }^{171 \mid}$ Furthermore, it is not certain that a specific treatment effect obtained with one IVIG preparation will also be obtained with another, since antibody titres against the most dangerous nosocomial bacteria may vary. ${ }^{[14,68]}$

Until recently, the largest studies, involving more than 300 patients, ${ }^{[64,70 \mid}$ did not reveal any benefit of IVIG on survival in patients with septicaemia. A trial that is intended to shed light on this question is ongoing, and will enrol about 800 patients. ${ }^{\text {172] }}$ Measurement of the extent to which reduction in some types of infections, shortening of ventilation time and benefit for selected patients may contribute to a reduction in hospital costs has not been evaluated in any of the studies.

\subsection{Preterm Neonates with Low Birthweight}

Preterm neonates with low birthweight are at high risk for infection. Maternal antibodies are transferred via the placenta, but not before the thirty-second week of gestation, while endogenous synthesis does not start until about 24 weeks after birth. Thus, preterm neonates might benefit from
IVIG therapy, especially with respect to nosocomial infections.

In a randomised, open, controlled study, Chirico et al. ${ }^{|73|}$ investigated 133 high-risk neonates with: (i) a gestational age of $\leq 34$ weeks and a birthweight of $<1500 \mathrm{~g}$; or (ii) assisted ventilation. Infants with low birthweight $(<1500 \mathrm{~g})$ receiving IVIG $0.5 \mathrm{~g} / \mathrm{kg}$ weekly for 1 month after birth had significantly fewer infections and a significantly reduced mortality compared with untreated patients, whereas infants with a birthweight of $>1500 \mathrm{~g}$ did not benefit from IVIG treatment.

Similarly, Baker and colleagues ${ }^{|74|}$ administered IVIG $0.5 \mathrm{~g} / \mathrm{kg}$ or placebo on enrolment ( 3 to 7 days after birth), after 1 and 2 weeks, and then every 14 days to 588 premature neonates. Infusions were continued until discharge or until 5 infusions had been given, whichever came first. In IVIG recipients, the incidence of infections was significantly reduced and the length of hospital stay was shortened, but the mortality rate was not influenced in comparison with placebo.

Weisman et al. ${ }^{|75|}$ observed no reduction in sepsis in 753 premature neonates (birthweight $500 \mathrm{~g}$ to $2000 \mathrm{~g}$ ) who received either a single dose of IVIG $0.5 \mathrm{~g} / \mathrm{kg}$ or albumin as placebo in a randomised, double-blind manner. Of these 753 patients, 31 had early signs of sepsis at inclusion, of whom 17 received placebo and 14 IVIG. Seven days after treatment, 5 of the albumin-treated children had died compared with only 2 in the IVIG group $(p<0.05)$. In contrast, Magny et al. ${ }^{[76]}$ did not observe any benefit of prophylactic IVIG treatment $(0.5 \mathrm{~g}$ given at the time of inclusion on day 1 and on days 2, 3, 17 and 31) in terms of reduction of nosocomial infections or mortality in 235 preterm neonates with an endotracheal tube and/or umbilical catheter when compared with placebo.

Furthermore, in a study by Fanaroff et al., ${ }^{1771}$ 2416 neonates (birthweight 500 to $1500 \mathrm{~g}$ ) were given IVIG $(0.9 \mathrm{~g} / \mathrm{kg}$ or $0.7 \mathrm{~g} / \mathrm{kg}$ in children with a bodyweight of $<1000 \mathrm{~g}$ or 1001 to $1500 \mathrm{~g}$, respectively) or placebo as prevention. Neither morbidity nor mortality were significantly influenced. Interestingly, only 1 of the 4 batches of IVIG used in 
Table IV. Other indications for intravenous immunoglobulin (IVIG)

\begin{tabular}{|c|c|c|c|c|}
\hline Indication & $\begin{array}{l}\text { Controlled } \\
\text { study? }\end{array}$ & Dosage $^{a}$ & Remarks & Reference \\
\hline $\begin{array}{l}\text { Alloimmunised } \\
\text { thrombocytopenia }\end{array}$ & Yes & $0.4 \mathrm{~g} / \mathrm{kg}$ for $2-5$ days & Case reports & 14,78 \\
\hline Rate-inhibitor haemophilia & No & $0.4 \mathrm{~g} / \mathrm{kg}$ for 5 days & $\begin{array}{l}\text { Case reports. Used when other therapeutic } \\
\text { options are failing }\end{array}$ & 14 \\
\hline $\begin{array}{l}\text { Lupus erythematosus- } \\
\text { induced thrombocytopenia }\end{array}$ & No & $0.4 \mathrm{~g} / \mathrm{kg}$ for $2-5$ days & Case reports & 14 \\
\hline Myasthenia gravis & No & $0.4 \mathrm{~g} / \mathrm{kg}$ for 5 days & $\begin{array}{l}122 \text { cases. Treatment effect after } 4 \text { to } 5 \text { days; } \\
\text { IVIG usually given when other treatment has } \\
\text { failed }\end{array}$ & 79 \\
\hline Multiple sclerosis & No & $0.4 \mathrm{~g} / \mathrm{kg}$ for 5 days bimonthly & $\begin{array}{l}10 \text { patients, } 10 \text { controls, } 3 \text { years observation } \\
\text { of patients. Significant reduction of symptom } \\
\text { recurrence }\end{array}$ & 80 \\
\hline Recurrent miscarriage & Yes & $\begin{array}{l}0.5 \mathrm{~g} / \mathrm{kg} \text { monthly } \\
\text { pre-conception until the fourth } \\
\text { month post-conception }\end{array}$ & $\begin{array}{l}60 \text { patients planned; study not yet completed. } \\
\text { Interim analysis shows significant benefit }\end{array}$ & 81 \\
\hline Asthma in children & No & $\begin{array}{l}1 \mathrm{~g} / \mathrm{kg} \text { for } 2 \text { days each month } \\
\text { for } 6 \text { months }\end{array}$ & $\begin{array}{l}8 \text { paediatric patients corticosteroid-resistant. } \\
\text { IVIG improves lung function }\end{array}$ & 82 \\
\hline Kawasaki disease & Yes & $0.4 \mathrm{~g} / \mathrm{kg}$ for 5 days & Together with aspirin (acetylsalicylic acid) & 51 \\
\hline Guillain-Barré syndrome & Yes & $0.4 \mathrm{~g} / \mathrm{kg}$ for 5 days & $\begin{array}{l}\text { Versus plasmapheresis in } 74 \text { patients. IVIG } \\
\text { was significantly superior with regard to } \\
\text { symptoms }\end{array}$ & 83 \\
\hline $\begin{array}{l}\text { Chronic inflammatory } \\
\text { demyelinating polyneuropathy }\end{array}$ & Yes & $0.4 \mathrm{~g} / \mathrm{kg}$ for 5 days & $\begin{array}{l}\text { Double-blind, placebo-controlled trial in } 28 \\
\text { patients. No difference with regard to } \\
\text { symptoms and electrophysiological signs }\end{array}$ & 84 \\
\hline
\end{tabular}

this study ${ }^{[77]}$ produced a significant reduction in infections.

In conclusion, the potential benefit of IVIG in preterm neonates has not been convincingly proven. Special targeted IgGs with antibodies against the most common neonatal pathogens may be of use.

\subsection{Other Indications for IVIG}

There are several diseases in which IVIG treatment has been reported to be effective, including neurological disorders with an immunological pathogenesis and other rare autoimmune diseases (table IV). Most of the clinical trials were either not controlled or involved an insufficient number of patients. Administration of IVIG in these indications is not encouraged in most of the published guidelines, ${ }^{[4-6]}$ which is in agreement with recent recommendations for the off-label use of IVIG. ${ }^{1851}$ Surprisingly, the (North American) National Insti- tutes of Health Consensus Conference on the use of $\mathrm{IVIG}^{[4]}$ did not consider the results of a large European trial of IVIG in Guillain-Barré syndrome, probably because no US investigators were involved. ${ }^{[86]}$ However, treatment of Guillain-Barré syndrome seems to be an accepted indication for IVIG as described in a North American consensus statement from 1995. ${ }^{[85]}$

\section{Pharmacoeconomic Aspects of IVIG}

Several guidelines and consensus papers on the use of immunoglobulins have been published. ${ }^{[3-6]}$ However, as research on the use of IVIG is ongoing, such recommendations must be reviewed at regular, relatively short, time intervals and should consider well-designed trials performed worldwide. ${ }^{[86]}$ Unfortunately, with the exception of leukaemia and CMV infection after renal transplantation, cost-effectiveness or cost-benefit analyses of the use of IVIG have not been published. 
In contrast to many other expensive or often used drugs, such as epoetin (recombinant human erythropoietin), granulocyte colony-stimulating factor (G-CSF), antiemetics and antiulcer drugs, pharmacoeconomic evaluations of IVIG have not been performed, even in established indications. The usefulness of IVIG in primary immunodeficiency may be indubitable, and cost calculations may seem unethical. However, treatment of CMV infection with ganciclovir (e.g. in BMT patients) is apparently much cheaper than, and at least as effective as, IVIG. ${ }^{|61|}$ Nevertheless, even if IVIG does not reduce mortality in sepsis patients (GCSF does not reduce mortality in neutropenic cancer patients), its use may shorten hospital stay and reduce antibiotic use, ${ }^{|64,54,67,68,70|}$ thereby decreasing healthcare expenditures.

\section{References}

1. Harder S, Böger R, Bode-Böger S, et al. Drug utilisation review in German hospitals [abstract]. Eur J Clin Pharmacol 1994; 47: 102

2. Thürmann P, Harder S. Determinants of hospital drug expenditures in Western Europe. PharmacoEconomics 1993; 4 (3): 157-61

3. Chapel HM, for the Consensus Panel for the Diagnosis and Management of Primary Antibody Deficiencies. Consensus on diagnosis and management of primary antibody deficiencies. BMJ 1994; 308: 581-5

4. National Institutes of Health Consensus Conference. Intravenous immunoglobulin: prevention and treatment of disease. JAMA 1990; 264: 3189-93

5. Keller T, McGrath K, Newland A, et al., for the Australasian Society of Blood Transfusion. Indications for use of intravenous immunoglobulin. Med J Aust 1993; 159: 204-6

6. Stiehm ER, Ashida E, Kim S, et al. Intravenous immunoglobulins as therapeutic agents (UCLA Conference). Ann Intern Med 1987; 107: 367-82

7. Cohn EJ, Gurd FRN, Suigenor DM, et al. A system for the separation of the components of human blood: quantitative procedure for the separation of the protein components of human plasma. J Am Chem Soc 1950; 72: 465-70

8. Jungi TW, Santer M, Lerch PG, et al. Effect of various treatments of gamma-globulin (IgG) for achieving intravenous tolerance on the capacity to interact with human monocyte $\mathrm{Fc}$ receptors: a comparative study. Vox Sang 1986; 51: 18-26

9. Morell A, Skavril F. Struktur und biologische Eigenschaften von Immunglobulinen: II. Eigenschaften von $\gamma$-GlobulinPräparaten. Schweiz Med Wochenschr 1980; 110: 80-5

10. Weisman LE. Advances in the treatment of neonatal sepsis and meningitis. Isr J Med Sci 1994; 30: 455-8

11. Janeway CA, Merler E, Rosen FS, et al. Intravenous gamma globulin: metabolism of gamma globulin fragments in normal and agammaglobulinemic persons. N Engl J Med 1968; 278 919-23
12. González M, Murature DA, Fidelio GD. Thermal stability of human immunoglobulins with sorbitol. Vox Sang 1995; 68: $1-4$

13. Yang $\mathrm{YH}, \mathrm{Ngo} \mathrm{C}$, Yeh IN, et al. Antibody $\mathrm{Fc}$ functional activity of intravenous immunoglobulin preparations treated with solvent-detergent for virus inactivation. Vox Sang 1994; 67: 33744

14. Nydegger U. Alte und neue Aspekte der intravenösen Immunglobulintherapie. Schweiz Med Wochenschr 1994; 124: $5-25$

15. Nowak T, Gregersen J-P, Klockmann U, et al. Virus safety of human immunoglobulins: efficient inactivation of hepatitis $\mathrm{C}$ and other human pathogenic viruses by the manufacturing procedure. J Med Virol 1992; 36: 209-16

16. Commission of the European Community. Validation of virus removal and inactivation procedures. 1991. III/8115/89-ENFinal 1991. In: Feiden K, editor. Arzneimittelprüf richtlinien. Stuttgart: Wissenschaftliche Verlagsgesellschaft, 1995

17. Imbach P, Perret BA, Babington R, et al. Safety of intravenous immunoglobulin preparations: a prospective multicenter study to exclude the risk of non-A, non-B hepatitis. Vox Sang 1991; 61: $1-4$

18. Louie RE, Galloway CJ, Dumas ML, et al. Inactivation of hepatitis $\mathrm{C}$ virus in low $\mathrm{pH}$ intravenous immunoglobulin. Biologicals $1994 ; 22$ : 13-9

19. Suomela $H$. Viral inactivation of blood and blood products. WHO LBS 1992; 92-5

20. Uemura $\mathrm{Y}$, Yang $\mathrm{YH}$, Heldebrant $\mathrm{CM}$, et al. Inactivation and elimination of viruses during preparation of human intravenous immunoglobulin. Vox Sang 1994; 67: $1-9$

21. Kempf C, Jentsch P, Poirier B, et al. Virus inactivation during production of intravenous immunoglobulin. Transfusion 1991; 31: 423-7

22. Bjøro K, Frøland SS, Yun Z, et al. Hepatitis $\mathrm{C}$ infection in patients with primary hypogammaglobulinemia after treatment with contaminated immunoglobulin. $\mathrm{N}$ Engl J Med 1994; 331: 1607-11

23. Lane RS. Non-A, non-B hepatitis from intravenous immunoglobulin. Lancet 1983; 2: 974-5

24. Weisman LE. The safety of intravenous immunoglobulin preparations. Isr J Med Sci 1994; 30: 459-63

25. Morell A, Skavril F, Barandun S. IgG-Subklassen der menschlichen Immunglobuline. Basel: S. Karger, 1975

26. Hammarström L, Gardulf A, Hammarström V, et al. Systemic and topical immunoglobulin treatment in immunocompromised patients. Immunol Rev 1994; 139: 43-70

27. Imbach P, Barandun S, d'Apuzzo V, et al. High-dose intravenous gammaglobulin for idiopathic thrombocytopenic purpura. Lancet 1981; I: 1228-31

28. Andersson UG, Björk L, Skansén-Saphir U, et al. Down-regulation of cytokine production and interleukin-2 receptor expression by pooled human IgG. Immunology 1993; 79: 211 -5

29. Glöckner WM. Kinetik von Immunoglobulin $G$ nach intravenöser und intramuskulärer Applikation. In: Kornhuber B, editor. Patient - Infektion - Immunoglobulin. Berlin: Springer Verlag, 1984: 33-8

30. Thürmann PA, Sonnenburg-Chatzopoulos C, Lissner R. Pharmacokinetic characteristics and tolerability of a novel intravenous immunoglobulin preparation. Eur J Clin Pharmacol 1995; 49: 237-42

31. Hagenbeek A, Brummelhuis HGJ, Donkers A, et al. Rapid clearance of cytomegalovirus-specific IgG after repeated intravenous infusions of human immunoglobulin into allogeneic 
bone marrow transplant recipients. J Infect Dis 1987; 155: 897-902

32. Mankarious S, Lee M, Fischer S, et al. The half-lives of IgG subclasses and specific antibodies in patients with primary immunodeficiency who are receiving intravenously administered immunoglobulin. J Lab Clin Med 1988; 112: 634-40

33. Fahey JF, Robinson AG. Factors controlling serum $\gamma$-globulin concentration. J Exp Med 1963; 118: 845-68

34. Theobald K, Högy B. Pharmacokinetics of single and multiple infusions of $5 \mathrm{~S}$ intravenous immunoglobulin. Vox Sang 1995; 68: 5-8

35. Dwyer J. Manipulating the immune system with immune globulin. N Engl J Med 1992; 326: 107-16

36. Stiehm ER. New uses for intravenous immune globulin. N Engl J Med 1991; 325: 123-5

37. Schaad UB, Gianella-Borradori A, Perret B, et al. Intravenous immunoglobulin in symptomatic paediatric human immunodeficiency virus infection. Eur J Pediatr 1988; 147: 300-3

38. Hague RA, Yap PL, Mok JYQ, et al. Intravenous immunoglobulin in HIV infection: evidence for the efficacy of treatment. Arch Dis Child 1989; 64: 1146-50

39. The National Institute of Child Health and Human Development Intravenous Immunoglobulin Study Group. Intravenous immunoglobulin for the prevention of bacterial infections in children with symptomatic human immunodeficiency virus infection. N Engl J Med 1991; 325: 73-80

40. Foon KA, Rai KR, Gale RP. Chronic lymphocytic leukemia: new insights into biology and therapy. Ann Intern Med 1990; 113: 525-39

41. Griffiths H, Brennan V, Lea J, et al. Crossover study of immunoglobulin replacement therapy in patients with low-grade B-cell tumors. Blood 1989; 73: 366-8

42. Cooperative Group for the Study of Immunoglobulin in Chronic Lymphocytic Leukemia. Intravenous immunoglobulin for the prevention of infection in chronic lymphocytic leukemia: a randomized, controlled clinical trial. N Engl J Med 1988; 319 : 902-7

43. Schedel I. Application of immunoglobulin preparations in multiple myeloma. In: Morell A, Nydegger UE, editors. Clinical use of intravenous immunoglobulins. London: Academic Press, 1986: 123-32

44. Chapel HM, Lee M, Hargreaves R, et al., for the UK Group for Immunoglobulin Replacement Therapy in Multiple Myeloma. Randomised trial of intravenous immunoglobulin as prophylaxis against infection in plateau-phase multiple myeloma. Lancet 1994; 343: 1059-63

45. Weeks JC, Tierney MR, Weinstein MC. Cost effectiveness of prophylactic intravenous immune globulin in chronic lymphocytic leukemia. N Engl J Med 1991; 325: 81-6

46. Pirofsky B, Kinzey DM. Intravenous immunoglobulins: a review of their uses in selected immunodeficiency and autoimmune diseases. Drugs 1992; 43: 6-14

47. Wordell CJ, Stubits EA, Tietze KJ, et al. Immune globulin in the treatment of autoimmune thrombocytopenic purpura. Clin Pharm 1985; 4: 206-13

48. ASHP therapeutic guidelines for intravenous immunoglobulin. Clin Pharm 1992; 11: 117-36

49. Kurlander R, Coleman RE, Moore J, et al. Comparison of the efficacy of a two-day and a five-day schedule for infusing intravenous gamma globulin in the treatment of immune thrombocytopenic purpura in adults. Am J Med 1987; 83 (4A): 17-24

50. Furusho K, Kamiya T, Nakano H, et al. High-dose intravenous gammaglobulin for Kawasaki disease. Lancet 1984; 2: 1055-8
51. Newburger JW, Takahashi M, Burns JC, et al. The treatment of Kawasaki syndrome with intravenous gamma globulin. $\mathrm{N}$ Engl J Med 1986; 315: 341-7

52. Guglielmo BJ, Wong-Beringer A, Linker CA. Immune globulin therapy in allogeneic bone marrow transplant: a critical review. Bone Marrow Transplant 1994; 13: 499-510

53. Winston DJ, Ho WG, Lin CH, et al. Intravenous immune globulin for prevention of cytomegalovirus infection and interstitial pneumonia after bone marrow transplantation. Ann Intern Med 1987; 106: 12-8

54. Sullivan KM, Kopecky KJ, Jocom J, et al. Immunomodulatory and antimicrobial efficacy of intravenous immunoglobulin in bone marrow transplantation. $\mathrm{N}$ Engl $\mathrm{J}$ Med 1990; 323: 705-12

55. Emanuel D, Taylor J, Brochstein J, et al. The use of intravenous immune globulin as prophylaxis for the infectious complications of allogeneic marrow transplantation [abstract no. 1075]. Blood 1992; 80 Suppl. 1: 271 A

56. Condie RM, O'Reilly RJ. Prevention of cytomegalovirus infection by prophylaxis with an intravenous, hyperimmune native, unmodified cytomegalovirus globulin: randomized trial in bone marrow transplant recipients. Am J Med 1984; 76 Suppl. 3A: 141

57. Kubanek B, Ernst P, Ostendorf P, et al. Preliminary data of a controlled trial of intravenous hyperimmune globulin in the prevention of cytomegalovirus infection in bone marrow transplant recipients. Transplant Proc 1985; 17: 468-9

58. Snydman DR, Werner BG, Tilney NL, et al. Final analysis of primary cytomegalovirus disease prevention in renal transplant recipients with a cytomegalovirus-immune globulin: comparison of the randomized and open-label trials. Transplant Proc 1991; 23 (1): 1357-60

59. Zbrozek AS. The cost of cytomegalovirus disease in renal transplantation [letter]. Transplantation 1994; 57 (1): 165

60. Conti DJ, Freed BM, Lempert N. Prophylactic immunoglobulin therapy improves the outcome of renal transplantation in recipients at risk for primary cytomegalovirus disease. Transplant Proc 1993; 25: 1421-2

61. Conti DJ, Freed BM, Gruber SA, et al. Prophylaxis of primary cytomegalovirus disease in renal transplant recipients. Arch Surg 1994; 129: 443-7

62. Nicol DL, MacDonald AS, Belitsky P, et al. Reduction by combination prophylactic therapy with CMV hyperimmune globulin and acyclovir of the risk of primary CMV disease in renal transplant recipients. Transplantation 1993; 55 (4): $841-6$

63. Stratta RJ, Taylor RJ, Bynon JS, et al. Viral prophylaxis in combined pancreas-kidney transplant recipients. Transplantation 1994; 57 (4): 506-12

64. The Intravenous Immunoglobulin Collaborative Study Group. Prophylactic intravenous administration of standard immunoglobulin as compared with core-lipopolysaccharide immune globulin in patients at high risk of postsurgical infection. $\mathrm{N}$ Engl J Med 1992; 327: 234-40

65. Glinz W, Grob PJ, Nydegger UE, et al. Polyvalent immunoglobulins for prophylaxis of bacterial infections in patients following multiple trauma. Intensive Care Med 1985; 11: 288-94

66. Just H-M, Metzger M, Vogel W, et al. Einfluß einer adjuvanten Immunglobulintherapie auf Infektionen bei Patienten einer operativen Intensiv-Therapie-Station. Klin Wochenschr 1986; 64: 245-56

67. Dominioni L, Dionigi R, Zanello M, et al. Effects of high-dose IgG on survival of surgical patients with sepsis scores of 20 or greater. Arch Surg 1991; 126: 236-40 
68. Schedel I, Dreikhausen U, Nentwig B, et al. Treatment of gramnegative septic shock with an immunoglobulin preparation: a prospective, randomized clinical trial. Crit Care Med 1991; 19: 1104-13

69. Nazzari C, Gaeta A, Lun MT, et al. Effect of intravenous immunoglobulin on opsonic activity and TNF production in patients at high risk for sepsis syndrome. Microbiologica 1993; 16: $251-8$

70. Jesdinsky HJ, Tempel G, Castrup HJ, et al. Cooperative group of additional immunoglobulin therapy in severe bacterial infections: results of a multicenter randomized controlled trial in cases of diffuse fibrinopurulent peritonitis. Klin Wochenschr 1987; 65: 1132-8

71. Siber GR. Immunoglobulin to prevent nosocomial infections. N Engl J Med 1992; 327: 269-71

72. Pilz P, Fateh-Moghadam S, Viell B, et al. Supplemental immunoglobulin therapy in sepsis and septic shock - comparison of mortality under treatment with polyvalent i.v. immunoglobulin versus placebo. Theor Surg 1993; 8: 61-83

73. Chirico G, Rondini G, Plebani A, et al. Intravenous gammaglobulin therapy for prophylaxis of infection in high-risk neonates. J Pediatr 1987; 110: 437-42

74. Baker CJ, Melish ME, Hall RT, et al. Intravenous immune globulin for the prevention of nosocomial infection in low-birthweight neonates. N Engl J Med 1992; 327: 213-9

75. Weisman LE, Stoll BJ, Kueser T, et al. Intravenous immunoglobulin therapy of neonatal sepsis. J Pediatr 1992; 121: 434-43

76. Magny J-F, Bremard-Oury C, Brault D, et al. Intravenous immunoglobulin therapy for prevention of infection in high risk premature infants: report of a multicenter, double-blind study. Pediatrics 1991; 88: 437-43

77. Fanaroff AA, Korones SB, Wright LL, et al. A controlled trial of intravenous immune globulin to reduce nosocomial infections in very-low-birth-weight infants. N Engl J Med 1994; 330: $1107-13$
78. Kickler T, Braine HG, Pinatadosi S, et al. A randomized placebo controlled trial of intravenous gammaglobulin in alloimmunized thrombocytopenic patients. Blood 1990; 75: 313-6

79. Schuchardt V. Behandlung neuromuskulärer Erkrankungen mit 7S-Ig. In: Zierz S, Langner G, Naß WP, editors. Immunmodulatorische Therapie mit Immunglobulinen bei Infektionen und Autoimmunerkrankungen. Jena: Universitätsverlag Jena, 1995

80. Achiron A, Pras E, Gilad R, et al. Open controlled therapeutic trial of intravenous immune globulin in relapsing-remitting multiple sclerosis. Arch Neurol 1992; 49: 1233-6

81. Coulam CB. Alternative treatment to lymphocyte immunization for treatment of recurrent spontaneous abortion. Am J Reprod Immunol 1994; 32: 286-9

82. Mazer BD, Gelfand EW. An open-label study of high-dose intravenous immunoglobulin in severe childhood asthma. J Allergy Clin Immunol 1991; 87: 976-83

83. Van der Meché FGA, Schmitz PIM, The Dutch Guillain-Barré Study Group. A randomized trial comparing intravenous immune globulin and plasma exchange in Guillain-Barré Syndrome. N Engl J Med 1992; 326: 1123-9

84. Vermeulen M, van Doorn PA, Brand A, et al. Intravenous immunoglobulin treatment in patients with chronic inflammatory demyelinating polyneuropathy: a double blind, placebo controlled study. J Neurol Neurosurg Psychiatry 1993; 56 (1): 36-9

85. Ratko TA, Burnett DA, Foulke GE, et al. Recommendations for off-label use of intravenously administered immunoglobulin preparations. JAMA 1995; 273: 1865-70

86. Consensus on IVIG [editorial]. Lancet 1990; 336: 470-2

Correspondence and reprints: Dr Petra Thürmann, Department of Clinical Pharmacology, University Hospital Frankfurt/Main, Theodor-Stern-Kai 7, D-60590 Frankfurt am Main, Germany. 